\title{
Histamine H2 Receptor Desensitization: Involvement of a Select Array of G Protein-Coupled Receptor Kinases
}

\author{
CARINA SHAYO, NATALIA FERNANDEZ, BIBIANA LEMOS LEGNAZZI, FEDERICO MONCZOR, ALEJANDRO MLADOVAN, \\ ALBERTO BALDI, and CARLOS DAVIO \\ School of Sciences (C.S.) and Radioisotopes Laboratory, School of Pharmacy and Biochemistry (N.F., B.L.L., F.M., C.D.), University of Buenos \\ Aires, Buenos Aires, Argentina; Institute of Biology and Experimental Medicine, Buenos Aires, Argentina (C.S., N.F., A.M., A.B.); and National \\ Research Council of Argentina, Buenos Aires, Argentina (F.M., A.B., C.D.)
}

Received January 4, 2001; accepted July 27, 2001

This paper is available online at http://molpharm.aspetjournals.org

\begin{abstract}
The histamine $\mathrm{H} 2$ receptor $(\mathrm{H} 2 \mathrm{r})$ belongs to the heptahelical receptor family; upon agonist binding, members of this family activate a $\mathrm{G}$ protein and the downstream effector adenylyl cyclase. Like other $\mathrm{G}$ protein-coupled receptors, exposure of $\mathrm{H} 2 \mathrm{r}$ to agonists produces a desensitization of the response. The present study focused on the desensitization mechanism of this receptor. Using transiently transfected COS-7 cells expressing tagged-H2r, the desensitization induced by amthamine, characterized by decreased cAMP production, was studied. Results show that the receptor was rapidly desensitized with a $t_{1 / 2}=0.49 \pm 0.01 \mathrm{~min}$. Because of the rapid nature of $\mathrm{H} 2 r$ desensitization, receptor phosphorylation was examined as a likely mechanism for signal attenuation. $\mathrm{H} 2 \mathrm{r}$ desensitization was not affected by protein kinases $\mathrm{A}$ and $\mathrm{C}$
\end{abstract}

(PKA and PKC) inhibitors but was remarkably reduced by $\mathrm{Zn}^{2+}$, an inhibitor of G protein-coupled receptor kinases (GRKs). Cotransfection experiments using tagged $\mathrm{H} 2 \mathrm{r}$ and different GRKs $(2,3,5$, or 6), demonstrated that GRK2 and GRK3 were the most potent in augmenting desensitization, causing a reduction in the maximal response to amthamine and a decrease of the $t_{1 / 2}$ for desensitization, whereas GRK5 and GRK6 did not affect the signaling. Receptor phosphorylation correlates with desensitization for each GRK studied, whereas phosphorylation that is dependent on protein kinases $\mathrm{A}$ and $\mathrm{C}$ seemed irrelevant in receptor signal termination. These results indicate that in $\mathrm{H} 2 \mathrm{r}-$ transfected COS-7 cells, exposure to an agonist caused desensitization controlled by $\mathrm{H} 2 \mathrm{r}$ phosphorylation via GRK2 and GRK3.
Histamine is an intercellular signal molecule that exerts its effect through H1, H2, and H3 receptors (Leurs et al., 1995). Molecular biology studies indicate that $H 2 r$ belongs to the large multigene family of $\mathrm{G}$ protein-coupled receptors (GPCRs) (Gantz et al., 1991). Structurally, these receptors are characterized by seven transmembrane $\alpha$-helices and functionally by their ability to transmit signals to effector molecules via G proteins (Dohlman et al., 1991). It is generally accepted that the $\mathrm{H} 2 \mathrm{r}$ mediates activation of adenylyl cyclase (AC) with subsequent increases in cAMP and protein kinase A (PKA) activation (Nonaka et al., 1992). A characteristic feature of these GPCRs is that in the face of continuing stimulation, signaling becomes attenuated or desensitized. For a large number of related GPCRs, rapid desensitization seems to involve receptor phosphorylation. $G$ protein-coupled receptor kinases (GRKs), and the second

This study was supported by grants from the University of Buenos Aires (JB52), the National Research Council of Argentina (PID 792/98), and the National Agency for Scientific and Technologic Promotion (PICT 1598). messenger-dependent kinases PKA and PKC, are responsible for the homologous and heterologous desensitization, respectively (Freedman and Lefkowitz, 1996). GRK-mediated phosphorylation of serine/threonine residues in the carboxyl tail and/or intracellular loops of GPCR increases the affinity for arrestin-type proteins, and this binding prevents any further coupling between the receptor and G proteins. The complex formed by the phosphorylated GPCR and arrestin targets the activated receptor to clathrin-coated pits for subsequent internalization (Pitcher et al., 1998).

Recent studies have described that the H2r-mediated cAMP response is rapidly desensitized in various cell types (Fukusima et al., 1993; Smit et al., 1994). However, in contrast to other GPCR, the mechanism of H2r desensitization is still not well understood. In the U937 promonocytic cell line, we described $\mathrm{H} 1$ and $\mathrm{H} 2$ histamine receptors (Davio et al., 1995 a), and we recently showed that the H2r was specifically desensitized by an $\mathrm{H} 2$ agonist with a $t_{1 / 2}$ of $\sim 20 \mathrm{~min}$. This desensitization proved to be homologous and involved the 
GRK family. Binding experiments showed that receptor internalization began just after $2 \mathrm{~h}$, when total desensitization took place (Lemos Legnazzi et al., 2000).

In an attempt to better understand the H2r desensitization mechanism, a transfection system that allowed the overexpression of the different GRKs was used. Results demonstrate that in COS-7 transfected cells, agonist-dependent H2r phosphorylation is coincident with receptor desensitization and involves GRK2 and GRK3 in both processes. A better knowledge of the molecular regulation of the H2r should contribute to the understanding and manipulation of the processes they regulate.

\section{Experimental Procedures}

Materials. Restriction enzymes were purchased from New England Biolabs, Inc. (Beverly, MA), and Taq polymerase from Invitrogen (Carlsbad, CA). Isobutylmethylxanthine (IBMX), cAMP, famotidine, pyrilamine, protease inhibitors, and phosphatase inhibitors were obtained from Sigma Chemical Company (St. Louis, MO). Amthamine, $N$-(2-aminoethyl)-5-isoquinolinesulphonamide (H9), and 6[2-(4-imidazolyl)ethylamino]- $N$-(4-trifluoromethylphenyl)heptanecarboxamide (HTMT dimaleate), were from Tocris Cookson Inc. (Ballwin, MO). $\left[{ }^{3} \mathrm{H}\right] \mathrm{cAMP}$ and $\left[{ }^{3} \mathrm{H}\right]$ tiotidine were purchased from New England Nuclear (Boston, MA), and $\left[{ }^{32} \mathrm{P}\right]$ orthophosphate from Amersham Pharmacia Biotech (Little Chalfont, Buckinghamshire, UK). All other chemicals were of analytical grade.

Expression Plasmid Preparation. Oligonucleotides were synthesized using the known cDNA sequence for human H2r, and a full-length nucleotide sequence was amplified from the human cell line U937 cDNA by polymerase chain reaction. The cDNA was then cloned into the SpeI and EcoRV sites of the eukaryotic expression vector pCEFL (pCEFL-H2r) (Teramoto et al., 1996) or into the BglII and $X b a \mathrm{I}$ sites of pCEFL-HA (pCEFL-HA-H2r), a modified pCEFL expression plasmid encoding the HA nonapeptide epitope. GRK2, -3, -5 , and -6 cDNAs were subcloned into the pCEFL vector (pCEFLGRK2, -3, -5, and -6). Plasmid purification was performed using reagents from QIAGEN Inc. (Valencia, CA) according to the manufacturer's instructions.

Cell Culture. COS- 7 cells were cultured at $37^{\circ} \mathrm{C}$ in a humidified atmosphere with $5 \% \mathrm{CO}_{2}$, in Dulbecco's modified Eagle's medium (DMEM) supplemented with $10 \%$ fetal calf serum and $50 \mu \mathrm{g} / \mathrm{ml}$ gentamicin.

Transfection. Transient transfections were performed by the DEAE-dextran technique. Cells plated in 35-mm dishes for cAMP production or in $100-\mathrm{mm}$ dishes for protein phosphorylation were transfected at $80 \%$ confluence using 0.3 to $3 \mu \mathrm{g}$ of each indicated plasmid. All assays were performed $48 \mathrm{~h}$ after transfection.

cAMP Determination. Transfected cells were incubated $3 \mathrm{~min}$ in DMEM supplemented with $1 \mathrm{mM}$ IBMX at $37^{\circ} \mathrm{C}$ and exposed $9 \mathrm{~min}$ to the agonist at the indicated concentrations. Cells were then washed with PBS and subjected to ethanol extraction followed by 5 -min centrifugation at $3000 \mathrm{~g}$. The supernatant was dried and resuspended in $50 \mathrm{mM}$ Tris-HCl buffer, $\mathrm{pH}$ 7.4. cAMP content was determined by means of competition with $\left[{ }^{3} \mathrm{H}\right] \mathrm{cAMP}$ for PKA, as described previously (Davio et al., 1995b) and expressed as the percentage of stimulation relative to maximal response.

Desensitization Experiments. Pretreatment of COS-7 cells transfected with amthamine was performed in DMEM at $37^{\circ} \mathrm{C}$ in a humidified atmosphere containing $5 \% \mathrm{CO}_{2}$. Cells were exposed to 10 $\mu \mathrm{M}$ (maximal response) amthamine for periods ranging from $5 \mathrm{~s}$ to 30 min in the absence of IBMX. Cells were then washed and resuspended in DMEM containing $1 \mathrm{mM}$ IBMX and exposed for 9 min to $10 \mu \mathrm{M}$ amthamine to determine whether the $\mathrm{AC}$ could still generate cAMP. Basal levels correspond to cells not rechallenged with the agonist.

To assay kinase inhibitors, cells were pretreated with $20 \mu \mathrm{M} \mathrm{H}$,
$20 \mu \mathrm{M}$ staurosporine, or $200 \mu \mathrm{M} \mathrm{ZnCl}_{2}$ for $20 \mathrm{~min}$ at $37^{\circ} \mathrm{C}$, followed by desensitization assays carried out in the presence of inhibitors. $\mathrm{Zn}^{2+}$ showed a maximal inhibition on desensitization response in the range of 100 to $400 \mu \mathrm{M}$. Higher concentrations became toxic for the cells. cAMP production is expressed as the stimulus relative to basal levels.

Radioligand Binding Assay. Triplicate assays were performed in COS-7 transfected cells in 24 multiwell plates. For saturation studies, increasing concentrations of $\left[{ }^{3} \mathrm{H}\right]$ tiotidine were incubated in the absence or presence of $1 \mu \mathrm{M}$ tiotidine, in a total volume of $200 \mu \mathrm{l}$ of $50 \mathrm{mM}$ Tris- $\mathrm{HCl}, \mathrm{pH}$ 7.4. After $40 \mathrm{~min}$ at $4^{\circ} \mathrm{C}$, incubation was stopped by dilution with $3 \mathrm{ml}$ of ice-cold $50 \mathrm{mM}$ Tris-HCl, $\mathrm{pH}$ 7.4, followed by washes with ice-cold buffer. Experiments on intact cells were carried out at $4^{\circ} \mathrm{C}$ to avoid internalization of the ligand. Kinetic studies showed that equilibrium was reached after $30 \mathrm{~min}$ and persisted for $4 \mathrm{~h}$ (data not shown).

Western Blots. COS-7 cells were lysed in sample buffer $(50 \mathrm{mM}$ Tris-HCl, pH 6.8, 2\% SDS, 100 mM 2-mercaptoethanol, 10\% glycerol, and $0.05 \%$ bromphenol blue), and sonicated to shear DNA. The anti-HA immunoprecipitates were also analyzed. Samples were boiled for $5 \mathrm{~min}$, and aliquots were electrophoresed in 12\% SDSpolyacrylamide gels and transferred to nitrocellulose membranes. The residual binding sites were blocked with 5\% nonfat powdered milk in PBS-Tween-20 (PBS containing 0.05\% Tween-20), and membranes were incubated with $1 \mu \mathrm{g} / \mathrm{ml}$ of anti-GRK2, 3, 5, 6 or anti-HA (for the immunoprecipitates) rabbit antibody (Santa Cruz Biotechnology, Santa Cruz, CA), in PBS-Tween-20. All subsequent washes were performed with the same buffer. Reactivity was developed using an anti-rabbit polyclonal antibody linked to horseradish peroxidase and enhanced chemiluminescence reagents, according to the manufacturer's instructions (Amersham Pharmacia Biotech).

Phosphorylation Assays. Transfected cells were preincubated $1 \mathrm{~h}$ at $37^{\circ} \mathrm{C}$ in phosphate-free DMEM, and labeled $3 \mathrm{~h}$ with 100 $\mu \mathrm{Ci} / \mathrm{ml}$ of ${ }^{32} \mathrm{P}_{\mathrm{i}}$ at $37^{\circ} \mathrm{C}$ in fresh medium. $\mathrm{H} 2$ agonist was applied as indicated in figure legends. To assay kinase inhibitors, cells were pretreated for $20 \mathrm{~min}$ with $20 \mu \mathrm{M}$ H9 or $200 \mu \mathrm{M} \mathrm{Zn}^{2+}$ at $37^{\circ} \mathrm{C}$, and agonist stimulation was carried out in the presence of inhibitors. The reaction was terminated by placing the cells at $4^{\circ} \mathrm{C}$ and washing twice with ice-cold PBS, followed by the addition of $1 \mathrm{ml} /$ plate of immunoprecipitation buffer $(150 \mathrm{mM} \mathrm{NaCl}, 50 \mathrm{mM}$ Tris- $\mathrm{HCl}, \mathrm{pH}$, $1 \%$ Nonidet P-40, 0.1\% SDS, $0.2 \mathrm{mM}$ EDTA, $10 \mathrm{mM}$ FNa, $1 \mathrm{mM}$ sodium vanadate, $1 \mathrm{mM}$ phenylmethylsulfonyl fluoride, $5 \mu \mathrm{M}$ aprotinin, $10 \mu \mathrm{M}$ leupeptin, and $5 \mu \mathrm{M}$ pepstatin). Lysed cells were centrifuged for $20 \mathrm{~min}$ at $12,000 \mathrm{~g}$ and $4^{\circ} \mathrm{C}$. The epitope-tagged $\mathrm{H} 2$ histamine receptor was immunoprecipitated from the supernatant by a 1 -h incubation with the specific anti-HA antibody at $4^{\circ} \mathrm{C}$. Immunocomplexes were recovered with the aid of Protein A/G-Sepharose (Santa Cruz Biotechnology) and washed 5 times with ice-cold immunoprecipitation buffer. Complexes were then dissociated by heating to $65^{\circ} \mathrm{C}$ for $10 \mathrm{~min}$ in sample buffer and separated by $12 \%$ SDS-polyacrylamide gel electrophoresis. Gels were dried and exposed to AGFA Curix RP1 films. ${ }^{32} \mathrm{P}$ labeling was quantified by the Scion Image 2000 software (Frederick, MD). Parallel anti-HA immunoprecipitates were processed for Western blot analysis of the HAH2r.

\section{Results}

Functional Expression of the Tagged H2r. The addition of the HA epitope to the $\mathrm{N}$ terminus of the human $\mathrm{H} 2 \mathrm{r}$ allowed the detection of the $\mathrm{H} 2$ histamine receptor by immunoprecipitation (antibodies against $\mathrm{H} 2 \mathrm{r}$ are not available). The tagged H2r cDNA was efficiently expressed when transfected into COS-7 cells, as judged by the immunodetection of a $42-\mathrm{kDa}$ band, using the anti-HA murine monoclonal antibody (Fig. 1). Bands of 58 and $25 \mathrm{kDa}$, respectively, corresponded to the heavy and light chains of the anti-HA used to 
form the immune complex. Binding experiments with cells transiently transfected with the native and the $\mathrm{N}$ terminal HA-H2r cDNA showed an important increase in the binding sites with respect to COS-7 cells, with an identical $K_{\mathrm{d}}$ value for $\left[{ }^{3} \mathrm{H}\right]$ tiotidine, an $\mathrm{H} 2$ selective ligand (Table 1 ).

In COS-7 cells transfected with pCEFL-H2r or with pCEFL-HA-H2r, the application of amthamine, an $\mathrm{H} 2$ agonist, elicited a dose-dependent cAMP production, with $\mathrm{EC}_{50}$ values of $62 \pm 20 \mathrm{nM}$ (mean \pm S.E.M., $n=3$ ) and $47 \pm 10 \mathrm{nM}$ (mean \pm S.E.M., $n=5$ ) for the native and N-terminal HAtagged $\mathrm{H} 2 \mathrm{r}$, respectively (Fig. 2). In the case of $\mathrm{HA}-\mathrm{H} 2 \mathrm{r}$ transfected cells, amthamine, but not HTMT dimaleate (H1 agonist), was able to induce cAMP production (Fig. 2 inset). The H2 agonist response was completely blocked by the H2 antagonist, famotidine, but not by pyrilamine, an $\mathrm{H} 1$ antagonist. The $\mathrm{EC}_{50}$ value for the COS-7 endogenous $\mathrm{H} 2 \mathrm{r}$ and the transfected HA-H2r were similar, whereas the $R_{\max }$ was 10 -fold higher in the transfected cells (Table 2). These results indicated that the addition of the HA epitope to the H2r does not alter the receptor localization, specificity, or signaling.

Desensitization of the HA-H2r in COS-7 Cells. H2r desensitization assays were performed in pCEFL-HA-H2rtransfected COS-7 cells. After pretreatment with $10 \mu \mathrm{M}$ amthamine ranging from $5 \mathrm{~s}$ to $30 \mathrm{~min}$, a decrease in cAMP production was observed when cells were rechallenged with the same agonist (Fig. 3A). Amthamine no longer induced a response when cells were pretreated for $5 \mathrm{~min}$, and halfmaximal desensitization was observed at $0.49 \pm 0.01 \mathrm{~min}$ (mean \pm S.E.M., $n=5$ ).

Because of the rapid nature of $\mathrm{H} 2 \mathrm{r}$ desensitization, receptor phosphorylation was evaluated as the likely mechanism for signal attenuation. To test this possibility, cAMP production was determined in desensitization assays from cells pretreated 0.5 min with $\mathrm{H} 2$ agonist in the presence of $\mathrm{H} 9$, staurosporine, and $\mathrm{Zn}^{2+}$ as inhibitors of PKA, PKC, and GRKs, respectively (Hasbi et al., 1998). Results indicated that neither PKA nor PKC inhibitors had any effect on desensitization, as judged by the similar levels of cAMP in cells pretreated with amthamine in the presence or absence of PKA and PKC inhibitors. However, pretreatment with $\mathrm{Zn}^{2+}$ completely blocked the desensitization of the $\mathrm{AC}$ response (Fig. 3B), suggesting that GRKs might play the predominant role in receptor phosphorylation in these cells.

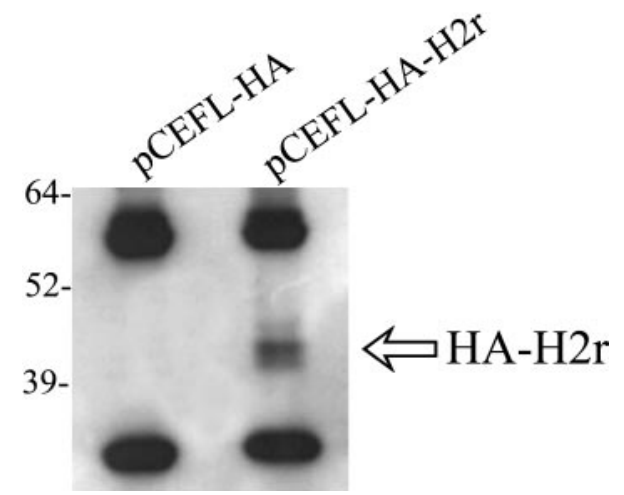

Fig. 1. Expression of tagged H2r. COS-7 cells were transfected with pCEFL-HA vector (control) or with pCEFL-HA-H2r. Western blots developed using anti-HA were performed on anti-HA immunoprecipitates from the corresponding cellular lysates, as described under Experimental Procedures. Molecular mass markers are indicated in kilodaltons.
Role of G Protein-Coupled Receptor Kinases in H2r Desensitization in COS-7 Cells. The involvement of the different GRKs in the signaling was studied by cotransfecting COS-7 cells with pCEFL-HA-H2r, and GRK2, -3, -5, or -6. The overexpression of the different GRKs was detected by Western blotting. The COS-7 endogenous GRKs expression was also detected, indicating GRK2, GRK3, and GRK5 expression (Fig. 4A). Signaling varied according to the GRK subtype overexpressed (Fig. 4B and Table 3), whereas GRK2 and 3 caused significant signal attenuation, reducing maximal cAMP accumulation by $52 \pm 11 \%$ (mean \pm S.E.M., $n=3$ )

TABLE 1

Binding of $\left[{ }^{3} \mathrm{H}\right]$ tiotidine in COS-7 cells

The $K_{\mathrm{d}}$ and $B_{\max }$ values were calculated using the equation for one binding site. The table shows the mean \pm S.E.M.; number of determinations $(n)$ is in parentheses. The $K_{\mathrm{d}}$ and $B_{\max }$ values of the pCEFL and the pCEFL-HAH2r and pCEFL-H2r were compared using an unpaired $t$ test and found to be significantly different $(* p<0.01)$.

\begin{tabular}{lcc}
\hline $\begin{array}{c}\text { COS-7 transfec- } \\
\text { tion }\end{array}$ & $K_{\mathrm{d}}$ & $B_{\max }$ \\
\hline & $n M$ & $\mathrm{fmol} / \mathrm{mg}$ \\
pCEFL & $19 \pm 5$ & $1.5 \pm 0.1(3)$ \\
pCEFL-HA-H2r & $21 \pm 6$ & $11.2 \pm 1.1(3)^{*}$ \\
pCEFL-H2r & $22 \pm 4$ & $12.4 \pm 1.5(3)^{*}$ \\
\hline
\end{tabular}

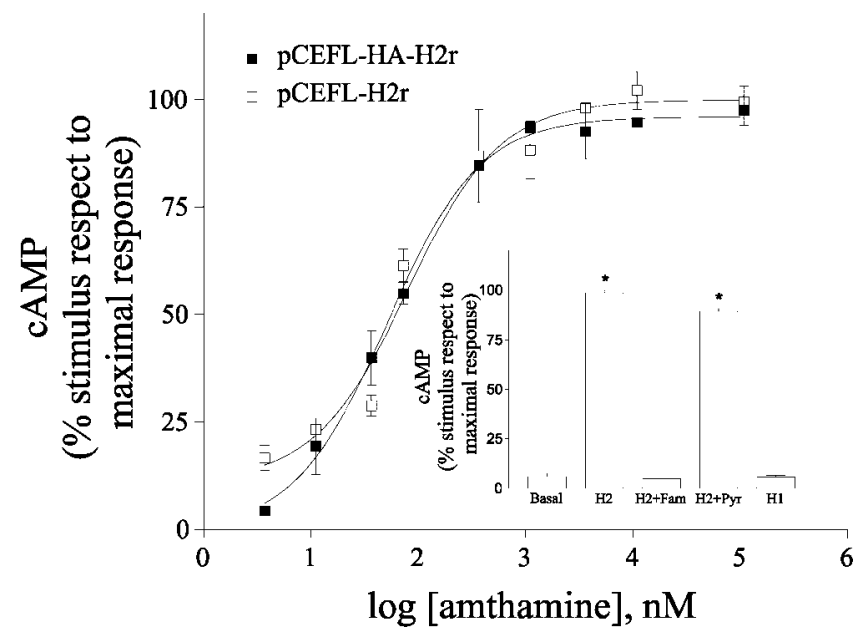

Fig. 2. Functional expression of tagged H2r. COS-7 cells were transfected with pCEFL-H2r or with pCEFL-HA-H2r. At $48 \mathrm{~h}$ after transfection, cells were incubated $9 \mathrm{~min}$ with increasing concentrations of amthamine at $37^{\circ} \mathrm{C}$ in the presence of $1 \mathrm{mM}$ IBMX, and cAMP levels determined. Data were calculated as the means \pm S.D. of assay triplicates. Similar results were obtained in at least three independent experiments. Inset, COS-7 cells were transfected with pCEFL-HA-H2r. At $48 \mathrm{~h}$ after transfection, cells were stimulated 9 min with $10 \mu \mathrm{M}$ amthamine (H2), $10 \mu \mathrm{M}$ HTMT dimaleate (H1), $10 \mu \mathrm{M}$ amthamine $+10 \mu \mathrm{M}$ famotidine (H2+Fam), or 10 $\mu \mathrm{M}$ amthamine $+10 \mu \mathrm{M}$ pyrilamine $(\mathrm{H} 2+\mathrm{Pyr})$ at $37^{\circ} \mathrm{C}$ in the presence of $1 \mathrm{mM}$ IBMX, and cAMP levels were determined. Data were calculated as the means \pm S.D. of assay triplicates. Similar results were obtained in at least three independent experiments. ${ }^{*} p<0.01$ compared with basal response.

TABLE 2

cAMP response in COS-7 cells

The $\mathrm{EC}_{50}$ and $R_{\max }$ values were calculated using the equation for dose response curve. The table shows the mean \pm S.E.M.; number of determinations $(n)$ is in parentheses. The $\mathrm{EC}_{50}$ and $R_{\max }$ values of the pCEFL-HA-H2r and the pCEFL were compared using an unpaired $t$ test and found to be significantly different ${ }^{*} p<$ $0.001)$.

\begin{tabular}{ccc}
\hline COS-7 transfection & EC $_{50}$ & $R_{\max }$ \\
\hline & $n M$ & pmol/well \\
pCEFL-HA-H2r & $48 \pm 10(5)$ & $540 \pm 35^{*}$ \\
pCEFL & $55 \pm 7(3)$ & $57 \pm 5$ \\
\hline
\end{tabular}


and $52 \pm 10 \%$ (mean \pm S.E.M., $n=3$ ), respectively, compared with COS-7 cells overexpressing only HA-H2r. However, GRK5 and 6 had no effect on signal generation. A shift to the right in the $\mathrm{H} 2$ agonist $\mathrm{EC}_{50}$ in GRK2- and GRK3cotransfected cells was also detected, but no effect was observed for GRK5 and GRK6 transfectants. On the other hand, binding experiments with $\left[{ }^{3} \mathrm{H}\right]$ tiotidine in cotransfected cells showed a decrease in the number of H2r in the cell membrane in GRK2- and GRK3-overexpressing cells (Fig. 4C and Table 4). Furthermore, COS-7 cells cotransfected with the pCEFL-HA-rH2 and GRK2 or -3 showed a shorter half-time of desensitization than control cells (cotransfected with pCEFL-HA-H2r and pCEFL). This is in contrast with cells overexpressing GRK5 or GRK6, which showed no differences in cAMP response after the desensitizing stimulus (Fig. 5, Table 5).

Role of G Protein-Coupled Receptor Kinases in H2r Phosphorylation. Because results indicated that GRK2
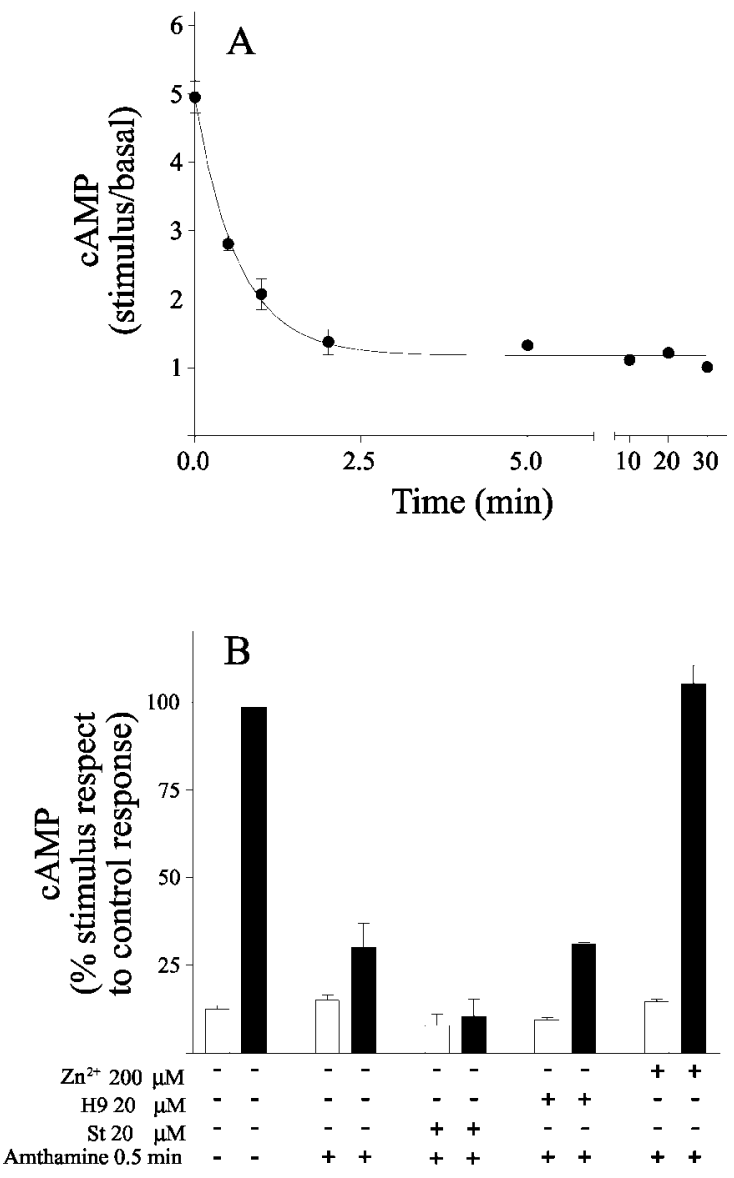

Fig. 3. Desensitization of the HA-H2-receptor. A, COS-7 cells were transfected with pCEFL-HA-H2r. At $48 \mathrm{~h}$ after transfection, cells were preincubated for different periods of time with $10 \mu \mathrm{M}$ amthamine, washed, and re-stimulated with $10 \mu \mathrm{M}$ amthamine in the presence of $1 \mathrm{mM}$ IBMX. cAMP production was determined as described under Experimental Procedures. Data were calculated as the means \pm S.E.M. of five independent experiments. B, COS-7 cells were transfected with pCEFL-HA-H2r. At $48 \mathrm{~h}$ after transfection, cells were pretreated 15 min with $20 \mu \mathrm{M} \mathrm{H} 9,20$ $\mu \mathrm{M}$ staurosporine (St), $200 \mu \mathrm{M} \mathrm{Zn}^{2+}$, or not pretreated, and exposed for $30 \mathrm{~s}$ to $10 \mu \mathrm{M}$ amthamine. Cells were then washed and stimulated with $10 \mu \mathrm{M}$ amthamine, in the presence of $1 \mathrm{mM}$ IBMX (filled bars). Basal levels correspond to nonstimulated cells (open bars). cAMP production was determined as described under Experimental Procedures. Data were calculated as the means \pm S.D. of assay triplicates. Similar results were obtained in at least three independent experiments. and -3 were involved in H2r desensitization, this process was correlated with receptor phosphorylation. Thus, COS-7 cells expressing the HA-H2r were labeled for $3 \mathrm{~h}$ with ${ }^{32} \mathrm{P}$ and
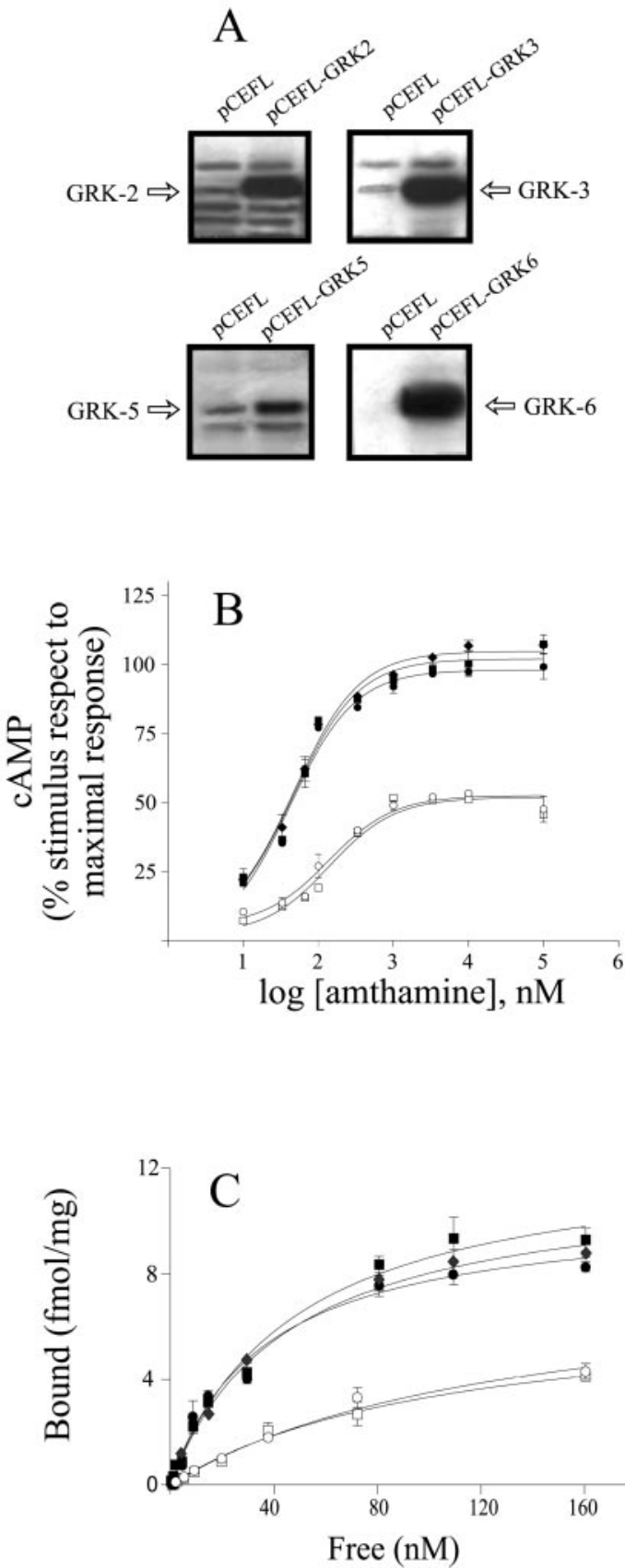

Fig. 4. Effects of GRK overexpression on H2r cAMP response and $\left[{ }^{3} \mathrm{H}\right] \mathrm{ti}-$ otidine binding. A, COS-7 cells were transfected with pCEFL (control) or pCEFL-GRK2, $-3,-5$, or -6 . At $48 \mathrm{~h}$ after transfection, cells were lysed as described under Experimental Procedures, and samples electrophoresed on $12 \%$ SDS-polyacrylamide gels, transfered to nitrocellulose, and incubated with polyclonal purified rabbit sera against GRK2, $-3,-5$, or -6. B, COS-7 cells were cotransfected with pCEFL-HA-H2r and pCEFL (匹), or with pCEFL-HA-H2r and pCEF/-GRK2 $(O),-3(\square),-5(\bullet)$, or -6 $(\bullet)$. At $48 \mathrm{~h}$ after transfection, cells were incubated 9 min with increasing concentrations of amthamine at $37^{\circ} \mathrm{C}$, in the presence of $1 \mathrm{mM}$ IBMX, and cAMP levels determined. Data were calculated as the means \pm S.E.M. of at least three independent experiments. C, saturation assay for $\left[{ }^{3} \mathrm{H}\right] \mathrm{ti}-$ otidine in intact COS-7 cells cotransfected with pCEFL-HA-H2r and pCEFL (ם), or with pCEFL-HA-H2r and pCEFL-GRK2 (O), $-3(\square),-5(\diamond)$, or $-6(\bullet)$. Data was calculated as the mean \pm S.E. of assay triplicates. Similar results were obtained in at least three independent experiments. 
subsequently treated with amthamine for different periods of time. The electrophoresis analysis of the immunoprecipitates showed that there is a clear agonist-promoted phosphorylation of the HA-H2r, which is dependent of time. After $30 \mathrm{~s}$ of stimulus, a clear increment in phosphorylation levels was observed that was maximal at 30 min (Fig. 6). When the phosphorylation assay was performed in COS-7 transfected cells pretreated with kinase inhibitors, $\mathrm{Zn}^{2+}$, but not $\mathrm{H} 9$, inhibited the phosphorylation induced by the H2 agonist,

\section{TABLE 3}

cAMP response in COS-7 cells overexpressing GRKs

The $\mathrm{EC}_{50}$ and $R_{\max }$ values were calculated from the data in Fig. $4 \mathrm{~B}$ using the equation for dose response curve. The table shows the mean \pm S.E.M.; number of determinations $(n)$ is in parentheses. The $\mathrm{EC}_{50}$ and $R_{\max }$ values of the pCEFL-HA$\mathrm{H} 2 \mathrm{r}$ and the pCEFL-GRK2 and GRK3 were compared using an unpaired $t$ test and found to be significantly different $(* p<0.01)$.

\begin{tabular}{ccc}
\hline COS-7 transfection & EC $_{50}$ & $R_{\max }$ \\
\hline & $n M$ & $\%$ \\
pCEFL-HA-H2r & $48 \pm 10(5)$ & $102 \pm 12$ \\
+ pCEFL-GRK2 & $137 \pm 18(3)^{*}$ & $52 \pm 11^{*}$ \\
+ pCEFL-GRK3 & $142 \pm 23(3)^{*}$ & $52 \pm 10^{*}$ \\
+ pCEFL-GRK5 & $48 \pm 13(3)$ & $98 \pm 15$ \\
+ pCEFL-GRK6 & $42 \pm 16(3)$ & $98 \pm 18$ \\
\hline
\end{tabular}

TABLE 4

Binding of $\left[{ }^{3} \mathrm{H}\right]$ tiotidine in cotransfected COS-7 cells

The $K_{\mathrm{d}}$ and $B$ values were calculated using the equation for one binding site. The table shows the mean + S.E.M. number of determinations $(n)$ is in parentheses. The $K_{\mathrm{d}}$ and $B_{\max }$ values of the pCEFL-HA-H2r and the pCEFL-GRK2 and pCEFL-GRK3 were compared using an unpaired $t$ test and found to be significantly different ${ }^{*} p<$ $0.001)$

\begin{tabular}{lcc}
\hline COS-7 transfection & $K_{\mathrm{d}}$ & $B_{\max }$ \\
\hline & $n M$ & $\mathrm{fmol} / \mathrm{mg}$ \\
pCEFL-HA-H2r & $21 \pm 6$ & $11.2 \pm 1.1(3)$ \\
+ GRK2 & $24 \pm 7$ & $5.2 \pm 1.1(3)^{*}$ \\
+ GRK3 & $25 \pm 6$ & $5.9 \pm 1.3(3)^{*}$ \\
+ GRK5 & $18 \pm 5$ & $10.5 \pm 1.2(3)$ \\
+ GRK6 & $19 \pm 4$ & $11.2 \pm 0.9(3)$ \\
\hline
\end{tabular}

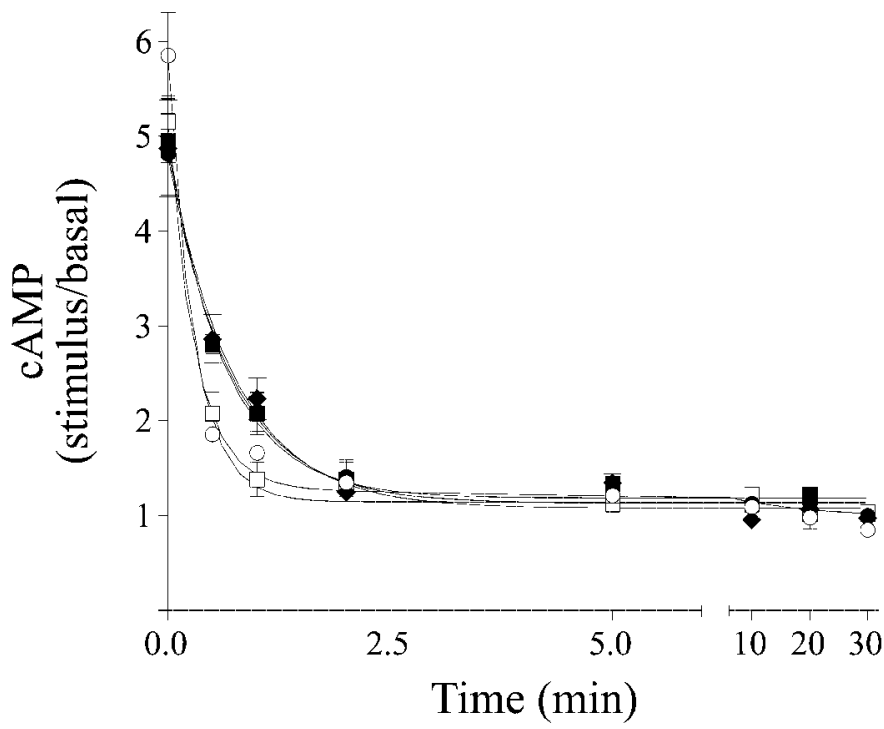

Fig. 5. Effects of GRK overexpression on desensitization. COS-7 cells were cotransfected with pCEFL-HA-H2r and pCEFL ( $\square$ ), or with pCEFLHA-H2r and pCEFL-GRK2 (○), $3(\square), 5(\diamond)$, or $6(\bullet)$. At $48 \mathrm{~h}$ after transfection, cells were preincubated for different periods of time with 10 $\mu \mathrm{M}$ amthamine, washed, stimulated with $10 \mu \mathrm{M}$ amthamine in the presence of $1 \mathrm{mM}$ IBMX, and cAMP production determined as described under Experimental Procedures. Data were calculated as the means \pm S.E.M. of at least three independent experiments. indicating the involvement of GRKs in H2r phosphorylation (Fig. 7). Phosphorylation of H2r was also assayed in cells overexpressing each GRK. Cells overexpressing GRK2 and -3 showed higher levels of H2r phosphorylation (161 $\pm 7 \%$ for GRK2, $155 \pm 4 \%$ for GRK3 cotransfections, compared with non-GRK-transfected, $p<0.01$ ). In contrast, levels of H2r phosphorylation were not modified upon overexpressing GRK5 or GRK6. The expression of the HA-H2r in all transfections was the same, as can be observed in the Western blot (Fig. 8).

\section{Discussion}

In this report, desensitization of the H2r in COS-7 transfected cells is shown to be mediated by phosphorylation. This desensitization seems to be homologous and induced by the $\mathrm{G}$ protein-coupled receptor kinases GRK2 and GRK3. Other GRKs assayed (GRK5 and GRK6) seem to play no role in this process.

TABLE 5

Desensitization of HA-H2r in COS-7 cells overexpressing GRK

The apparent rate of desensitization was calculated from the data in Fig. 4C using the equation for monoexponential decay. The table shows the mean \pm S.E.M.; number of determinations $(n)$ is in parentheses. The apparent rate of desensitization of the pCEFL-HA-H2r and the pCEFL-GRK2 and GRK3 were compared using an unpaired $t$ test and found to be significantly different $\left({ }^{*} p<0.01\right)$

\begin{tabular}{cc}
\hline COS-7 transfection & \multicolumn{1}{c}{$t_{1 / 2}$} \\
\hline & $\min$ \\
pCEFL-HA-H2r & $0.49 \pm 0.01(5)$ \\
+ pCEFL-GRK2 & $0.25 \pm 0.05(3)^{*}$ \\
+ pCEFL-GRK3 & $0.30 \pm 0.01(3)^{*}$ \\
+ pCEFL-GRK5 & $0.45 \pm 0.05(3)$ \\
+ pCEFL-GRK6 & $0.48 \pm 0.02(3)$ \\
\hline
\end{tabular}
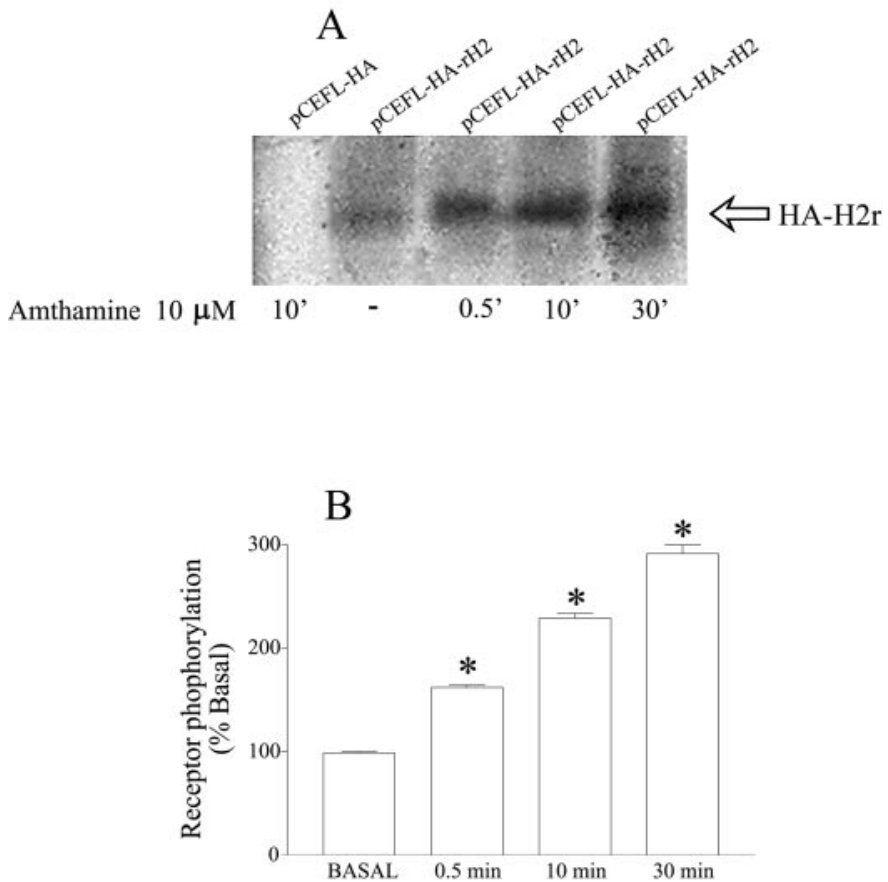

Fig. 6. Time course of phosphorylation of H2r induced by amthamine. A, COS-7 cells were transfected with pCEFL-HA-H2r. After ${ }^{32} \mathrm{P}$ incorporation, cells were pretreated for different periods of time with $10 \mu \mathrm{M}$ amthamine. Receptor phosphorylation was determined as described under Experimental Procedures. B, ${ }^{32} \mathrm{P}$ labeling was quantified using the Scion Image program. Data were calculated as the means \pm S.E.M. of three experiments. ${ }^{*} p<0.01$ compared with basal phosphorylation. 
As a first step, an N-terminal tag (HA) was incorporated to the H2r, and expression and function of this receptor were evaluated. Transfection of COS-7 cells with the pCEFL-HAH2r localizes the HA-H2r in the plasmatic cell membrane, as judged by binding experiments. The specificity for the $\mathrm{H} 2$ agonist was maintained, and, in a dose-response assay, the HA-epitope did not alter the $\mathrm{EC}_{50}$ value for cAMP response. It is interesting to mention that the modification of the $\mathrm{N}$ terminal portion did not affect receptor signaling. Therefore, we considered the HA-tagged receptor a suitable tool for desensitization and phosphorylation studies. Other reports however, show that the presence of an $\mathrm{N}$-terminal epitope could increase or decrease signaling by unclear mechanisms, perhaps involving changes in the receptor conformation (Shetzline et al., 1998).

Cellular responses to agonists of $\mathrm{G}$ protein-coupled receptors are rapidly attenuated. Mechanisms of signal attenuation include ligand removal from the extracellular fluid, desensitization of receptor function (uncoupling), endocytosis, and down-regulation. An important component of desensitization, which occurs within seconds to minutes of receptor activation, is the uncoupling of the activated receptors from their G protein by receptor phosphorylation (Grady et al., 1997).

In our experiments, the time course for the attenuation of the signal of the H2r in COS-7 transfected cells was quite rapid $\left(t_{1 / 2}=0.49 \pm 0.01 \mathrm{~min}\right)$, suggesting the involvement of
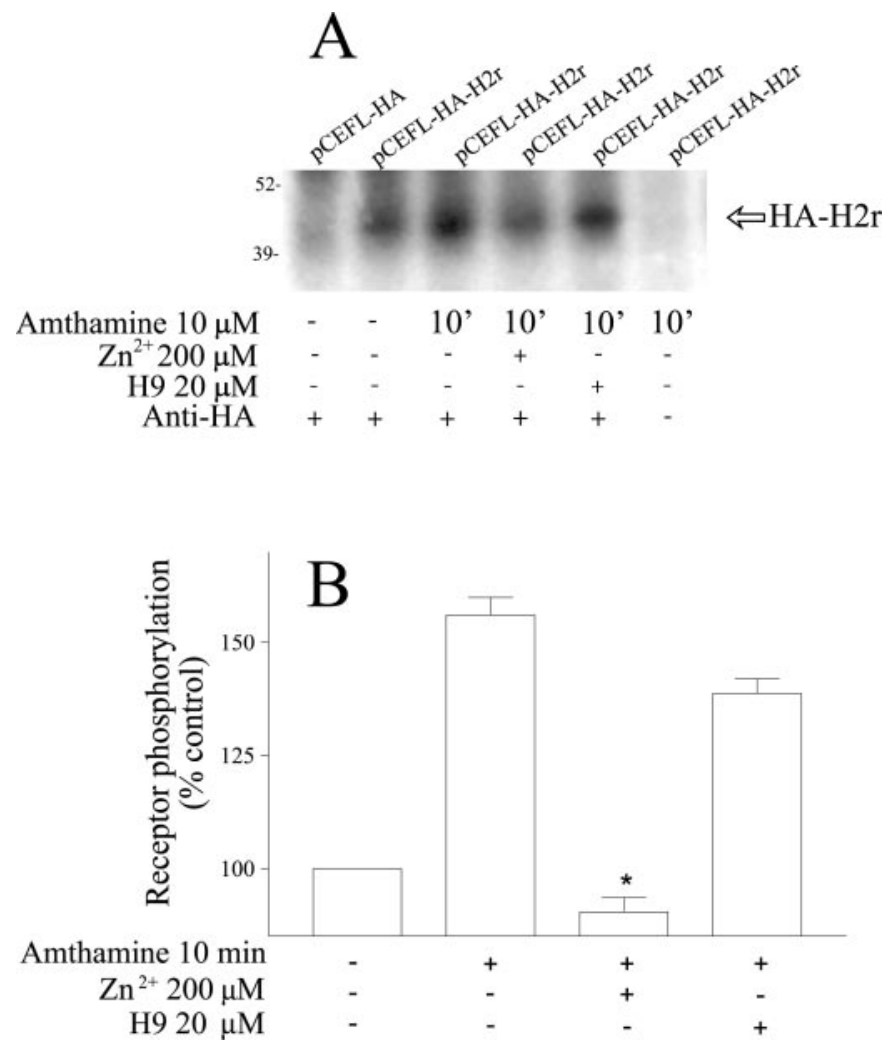

Fig. 7. Effect of kinase inhibitors on HA-H2r phosphorylation. A, COS-7 cells were transfected with pCEFL-HA-H2r. After ${ }^{32} \mathrm{P}$ incorporation, cells were pretreated 20 min with $200 \mu \mathrm{M} \mathrm{Zn}^{2+}$ or $20 \mu \mathrm{M} \mathrm{H} 9$, and stimulated $10 \mathrm{~min}$ with $10 \mu \mathrm{M}$ amthamine. Receptor phosphorylation was determined as described under Experimental Procedures. B, ${ }^{32} \mathrm{P}$ labeling was quantified using the Scion Image program. Data were calculated as the means \pm S.E.M. of three experiments. ${ }^{*} p<0.01$ compared with agoniststimulated phosphorylation. receptor phosphorylation. In previous experiments, carried out in promonocytic U937 cells, a slower time of H2r desensitization with a $t_{1 / 2}=20 \mathrm{~min}$ had been described (Shayo et al., 1997). In addition, promyelocytic HL-60 cells showed a slower time than COS-7 transfected cells (Sawutz et al., 1984), suggesting a dependence of the cellular environment on the desensitization process.

Two lines of evidence support the concept that GRKs are involved in the desensitization mechanism in COS-7 transfected cells. First, desensitization was not affected by the presence of $10 \mu \mathrm{M}$ H9, a PKA inhibitor, or $20 \mu \mathrm{M}$ staurosporine, a PKC inhibitor, indicating that there was no heterologous component in the desensitization process described. Nevertheless, $200 \mu \mathrm{M} \mathrm{Zn}^{2+}$, a GRK inhibitor, seemed to inhibit desensitization. Second, in cotransfection experiments involving $\mathrm{H} 2 \mathrm{r}$ and different GRKs $(2,3,5$, or 6$)$, a decrease in the cAMP response and a rightward shift of the $\mathrm{EC}_{50}$ were detected when cells were overexpressing GRK2 or GRK3. In desensitization experiments, there was a significant decrease in the $t_{1 / 2}$ of desensitization in cells cotransfected with the H2r and GRK2 or GRK3, although transfection with GRK5 and GRK6 showed levels similar to those of control cells. These results indicate that the GRKs involved in the process of desensitization are GRK2 and GRK3.

Binding experiments indicated that GRK2 and GRK3 overexpression decreased the number of H2rs in cell membrane. This evidence denoted a basal regulation of the H2r by GRK2 and GRK3 because of the high expression of these kinases.

Desensitization of histamine H2r has been noted in the human leukemia cell line HL-60, the human promonocytic
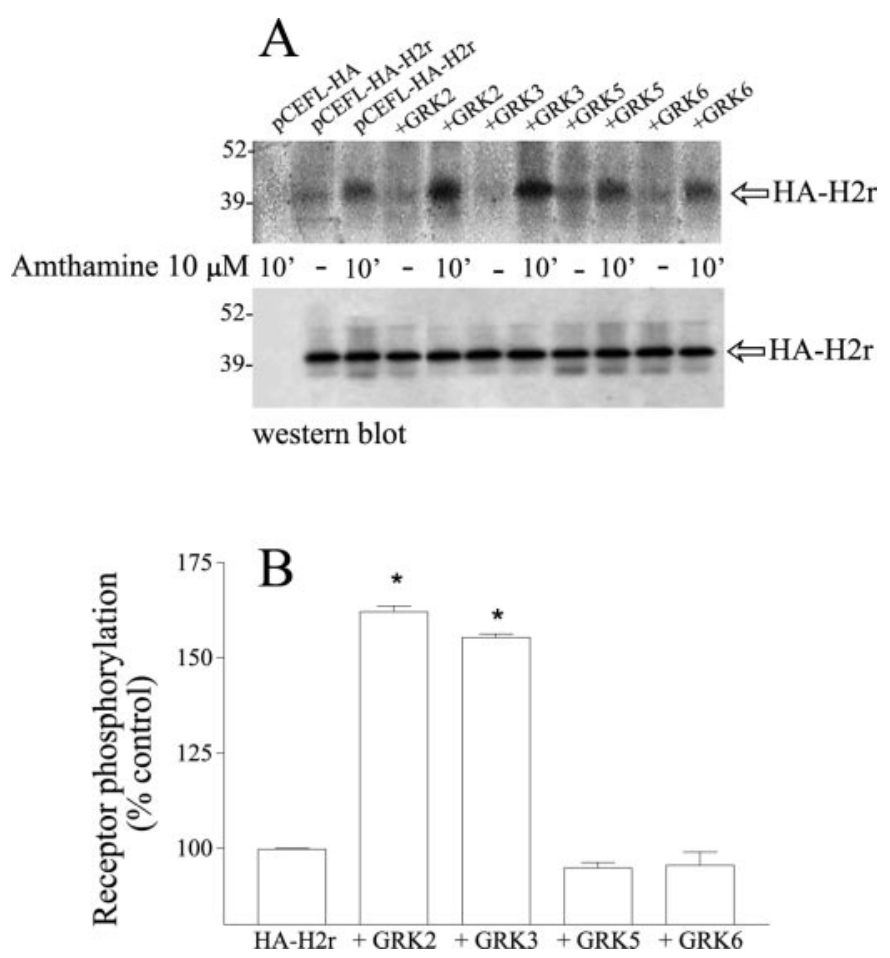

Fig. 8. Effect of GRK overexpression on HA-H2r phosphorylation. A, COS-7 cells were transfected with pCEFL-HA-H2r, or pCEFL-HA-H2r plus GRK2, -3 , -5 , or -6 . After ${ }^{32} \mathrm{P}$ incorporation, cells were stimulated 10 min with $10 \mu \mathrm{M}$ amthamine, and receptor phosphorylation and expression (Western blot) were determined as described under Experimental Procedures. B, ${ }^{32} \mathrm{P}$ labeling was quantified by the Scion Image program. Data were calculated as the means \pm S.E.M. of three experiments. ${ }^{*} p<$ 0.01 compared with non GRK-transfected. 
cell line U937, and the human adenocarcinoma cell line MKN-45 (Sawutz et al., 1984; Nakata et al., 1996; Shayo et al., 1997). Homologous and heterologous desensitization has been observed in the case of HL-60 cells. For U937, MKN-45, and COS-7 transfected cells, homologous, but not heterologous, cAMP desensitization was described.

Data have recently emerged suggesting the involvement of GRKs in the desensitization of a receptor other than the well-characterized $\beta_{2}$-adrenergic receptor (Benovic et al., 1986; Lohse et al., 1990), as seems to be the case for the $\alpha_{1 \mathrm{~B}}$-adrenergic receptor (Diviani et al., 1996), the $\alpha_{2}$-adrenergic receptors (Kurose and Lefkowitz, 1994), the $\beta_{1}$-adrenergic receptor (Freedman et al., 1995), the $\mathrm{m}_{1}$ muscarinic receptor (Haga et al., 1996), the $\mathrm{m}_{2}$ and $\mathrm{m}_{3}$ muscarinic receptors (Debburman et al., 1995), the thrombin receptor (Ishii et al., 1994), the $N$-formyl peptide receptor (Prossnitz et al., 1995), the $\delta$-opioid receptor (Hasbi et al., 1998), and the secretin receptor (Shetzline et al., 1998). For many of these, a preferential participation of various GRKs has been demonstrated (Pitcher et al., 1998).

Finally, this study directly demonstrates the agonist-dependent $\mathrm{H} 2 \mathrm{r}$ phosphorylation, by specific immunoprecipitation of an N-terminal HA-tagged receptor. Phosphorylation kinetics was time-dependent reaching maximal levels at 30 min after agonist treatment. We have routinely used $10 \mathrm{~min}$ of treatment for methodological reasons. To explain our results, we speculate about the existence of a mechanism of multiple phosphorylation within the H2r molecule that in turn evokes a progressive cascade response. Thus, the first phosphorylative event, at brief time, could preclude the receptor ability to increase cAMP levels. Subsequent H2r phosphorylation (as judged by the increment in ${ }^{32} \mathrm{P}$ incorporation), could be involved in the internalization and recycling processing. At $0.5 \mathrm{~min}$, we observed an increase of the basal phosphorylation paralleling the half-time of desensitization. Concomitant with desensitization assays, receptor phosphorylation was not modified in the presence of PKA or PKC inhibitors, whereas a GRK inhibitor abolished receptor phosphorylation. In the same way, overexpression of GRK2 and GRK3, but not GRK5 and GRK6, produced an enhancement of phosphorylation, indicating the importance of these GRKs in the H2r phosphorylation. On the other hand, Western blot of the immunoprecipitated fraction from COS-7 cells cotransfected with various GRKs showed no differences in the H2r level. This indicates that the decrease in the number of $\mathrm{H} 2 \mathrm{r}$ in the cell membrane was a consequence of GRK2 and GRK3 overexpression, causing an augmentation in H2r internalization by basal phosphorylation. Even with the lower expression of H2r in membrane of GRK2- and GRK3-transfected cells, the phosphorylation induced by the agonist was drastically increased.

GRK substrate specificity is consistent with a number of key differences among the mammalian kinases cloned to date. For example, these kinases seem to possess distinct mechanisms responsible for their localization to the cell membrane. GRK2 and GRK3 contain binding sites within their $\mathrm{C}$ termini for the $\beta \gamma$ subunits of heterotrimeric $\mathrm{G}$ proteins (Koch et al., 1993; Pitcher et al., 1995), whereas GRK5 seems to be constitutively associated with the membrane, possibly because of a stretch of basic amino acids localized in its $\mathrm{C}$ terminus that interact with phospholipid head groups (Premont et al., 1994). The mechanism for membrane local- ization of GRK6 seems to involve its palmitoylation (Stoffel et al., 1994). The substrate specificity of the various kinases, as determined by peptide studies, has also been shown to differ. Whereas GRK2 and GRK3 preferentially phosphorylate serine or threonine residues $\mathrm{C}$-terminal to aminoacidic acids (Onorato et al., 1991), GRK5 and GRK6 do not display such a preference. Another difference among these kinases involves their regulation. Although GRK5 is autophosphorylated (Kunapuli et al., 1994), probably leading to its activation, GRK2, GRK3, and GRK6 are not (Loudon and Benovic, 1994). Mammalian cDNAs encoding six $\mathrm{G} \beta$ subunits (Watson et al., 1996) and $12 \mathrm{G} \gamma$ subunits (Ray et al., 1995) have been identified, combining to form a multitude of potential $\mathrm{G} \beta \gamma$ combinations. GRK2 and GRK3 exhibit specificity for the distinct $\mathrm{G} \beta \gamma$ combination. In the MKN-45 cell line, GRK2 was described as responsible for the desensitization of the H2r (Nakata et al., 1996), whereas in COS-7 transfected cells, we have demonstrated the participation of both GRK2 and GRK3. This observation suggests that the H2r may be coupled with different combinations of $\mathrm{G} \beta \gamma$ isoforms in each cell line studied.

With the surfeit of receptors and relative scarcity of GRKs, it seems that each GRK regulates innumerable receptors, probably in a cell-type-specific manner. That is, regulation of a given receptor in a particular cell will be determined not only by the GRKs expressed in that cell but also by the relative and absolute expression levels of each GRK in that cell (Pitcher et al., 1998). In that sense, $\alpha_{2 \mathrm{~A}}$ and $\alpha_{2 \mathrm{~B}}$-adrenergic receptors (Jewell-Motz and Liggett, 1996), $\mathrm{m}_{3}$ acetylcholine receptor (Debburman et al., 1995), and substance P receptor (Kwatra et al., 1993) are all regulated by GRK2 and 3.

Overall, our results demonstrate that rapid desensitization and phosphorylation of the $\mathrm{H} 2 \mathrm{r}$ in COS-7 transfected cells seem to be controlled by protein kinase(s) belonging to the GRK family (GRK2 and GRK3) that are independent of PKA and PKC activities. These results emphasize the importance of GRKs in regulating GPCR function in a significant number of vital processes, suggesting that disorders of selected GRKdependent functions could contribute to, if not engender, disease. Further studies are necessary to obtain more detailed knowledge of the molecular events occurring during the desensitization of the $\mathrm{H} 2$ histamine receptor.

\section{Acknowledgments}

We are sincerely grateful to Dr. J. F. Benovic (Philadelphia, PA) for the GRK2, -3, -5 and -6 cDNAs and Dr. O. Coso (Buenos Aires, Argentina) for the expression vectors pCEFL and pCEFL-HA.

\section{References}

Benovic JL, Strasser RH, Caron MG and Lefkowitz (1986) Beta adrenergic receptor kinase: identification of a novel protein kinase that phosphorylates the agonist occupied form of the receptor. Proc Natl Acad Sci USA 83:2797-2801

Davio C, Cricco G, Bergoc R, and Rivera E (1995 a) $\mathrm{H}_{1}$ and $\mathrm{H}_{2}$ histamine receptors in N-nitroso-N-methylurea (NMU)-induced carcinomas with atypical coupling to signal transducers. Biochem Pharmacol 50:91-96.

Davio C, Baldi A, Shayo C, Brodsky A, Cricco G, Bergoc R, and Rivera E (1995 b) $\mathrm{H}_{1}$ and $\mathrm{H}_{2}$ histamine receptors in histiocytic lymphoma cell line U937. Inflamm Res 44:S72-S73.

Debburman SK, Kunapuli P, Benovic JL, and Hosey MM (1995) Agonist-dependent phosphorylation of human muscarinic receptors in Spodoptera frugiperda insect cell membranes by G protein-coupled receptor kinases. Mol Pharmacol 47:224233.

Diviani D, Lattion AL, Larbi N, Kunapuli P, Pronin A, Benovic JL, and Cotecchia S (1996) Effect of different $\mathrm{G}$ protein-coupled receptor kinases on phosphorylation and desensitization of the $\alpha_{1 \mathrm{~B}}$-adrenergic receptor. J Biol Chem 271:5049-5058. Dohlman HG, Thorner J, Caron MG, and Lefkowitz R (1991) Model systems for the 
study of seven-transmembrane segment receptors. Annu Rev Biochem 60:653688

Freedman N and Lefkowitz R (1996) Desensitization of G proteins coupled-receptors. Recent Prog Horm Res 51:319-353.

Freedman NJ, Liggett SB, Brachman DE, Pei G, Caron MG, and Lefkowitz RJ (1995) Phosphorylation and desensitization of the human adrenergic receptor. $J$ Biol Chem 270:17953-17961.

Fukusima Y, Oka Y, Katagiri H, Saitoh T, Asano T, Ishihara H, Matsuhashi N, Kodama T, Yazaki Y, and Sugano K (1993) Desensitization of canine H2 receptor expressed in Chinese hamster ovary cells. Biochem Biophys Res Commun 190: $1149-1145$.

Gantz I, Schaffer M, Del Valle J, Logdson C, Campbell V, Uhler M, and Yamada T (1991) Molecular cloning a gene encoding the histamine $\mathrm{H}_{2}$ receptor. Proc Natl Acad Sci USA 88:429-433.

Grady EF, Böhm KS, and Bunnett NW (1997) Turning of the signal: mechanisms that attenuate signaling by G protein-coupled receptors Am J Physiol 273:G586G601.

Haga K, Kameyama K, Haga T, Kikkawa U, Shiozaki K, and Uchiyama H (1996) Phosphorylation of human $\mathrm{m} 1$ muscarinic acetylcholine receptors by $\mathrm{G}$ proteincoupled receptor kinase 2 and protein kinase C. J Biol Chem 271:2776-2782.

Hasbi A, Polastron J, Allouche S, Stanasila L, Massotte D, and Jauzac P (1998) Desensitization of the $\delta$ opioid receptor correlates with its phosphorylation in SK-N-BE cells: involvement of a G protein-coupled receptor kinase. J Neurochem 70:2129-2138.

Ishii K, Ghen J, Ishii M, Koch WJ, Freedman NJ, Lefkowitz RJ, and Canghlin SR (1994) Inhibition of thrombin receptor signaling by a G-protein coupled receptor kinase. J Biol Chem 269:1125-1130.

Jewell-Motz EA and Liggett SB (1996) G protein-coupled receptor kinase specificity for phosphorylation and desensitization of $\alpha_{2}$ adrenergic subtypes. $J$ Biol Chem 271:18082-18087.

Koch WJ, Inglese J, Stone WC, and Lefkowitz RJ (1993) The binding site for the beta gamma subunits of heterotrimeric $\mathrm{G}$ proteins on the beta-adrenergic receptor kinase. J Biol Chem 268:8256-8260.

Kwatra MM, Schwinn DA, Schreurs J, Blank JL, Kim CM, Benovic JL, Krause JE Caron MG, and Lefkowitz RJ (1993) The substance P receptor, which couples to $\mathrm{Gq} / 11$, is a substrate of beta-adrenergic receptor kinase 1 and 2 . J Biol Chem 268:9161-9164.

Kunapuli P, Gurevich VV, and Benovic JL (1994) Phospholipid-stimulated autophosphorylation activates the G protein-coupled receptor kinase GRK5. J Biol Chem 269:10209-10212.

Kurose H and Lefkowitz RJ (1994) Differential desensitization and phosphorylation of three cloned and transfected $\alpha_{2}$-adrenergic receptor subtypes. J Biol Chem 269:10093-10099.

Lemos Legnazzi B, Shayo C, Monczor F, Martin ME, Fernandez N, Brodsky A, Baldi A, and Davio C (2000) Rapid desensitization and slow recovery of the cyclic AMP response mediated by histamine $\mathrm{H} 2$ receptors in U937 cell line. Biochem Pharmacol 60:159-166.

Leurs R, Smit MJ, and Timmerman H (1995) Molecular pharmacological aspects of histamine receptors. Pharmacol Ther 66:413-463.

Lohse MJ, Benovic JL, Caron MG, and Lefkowitz RJ (1990) Multiple pathways of rapid $\beta 2$-adrenergic receptor desensitization. J Biol Chem 265:3202-3209.

Loudon RJ and Benovic JL (1994) Expression, purification, and characterization of the G protein-coupled receptor kinase GRK6. J Biol Chem 269:22691-22697.

Nakata H, Kinoshita Y, Kishi K, Fukuda H, Kawanami C, Matsushina Y, Asahara
M, Okada A, Maekawa T, and Chiba T (1996) Involvement of $\beta$-adrenergic receptor kinase- 1 in homologous desensitization of histamine $\mathrm{H}_{2}$ receptors in human gastric carcinoma cell line MKN-45. Digestion 57:406-410.

Nonaka T, Mio M, Doi M, and Tasaka K (1992) Histamine-induced differentiation of HL-60 cells. The role of cAMP and protein kinase A. Biochem Pharmacol 44:11151121.

Onorato JJ, Palczewski K, Regan JW, Caron MG, Lefkowitz RJ, and Benovic JL (1991) Role of acidic amino acids in peptide substrates of the beta-adrenergic receptor kinase and rhodopsin kinase. Biochemistry 30:5118-5125.

Pitcher JA, Freedman NJ, and Lefkowitz J (1998) G protein-coupled receptor kinases. Annu Rev Biochem 67:653-692.

Pitcher JA, Touhara K, Payne ES, and Lefkowitz RJ (1995) Pleckstrin homology domain-mediated membrane association and activation of the beta-adrenergic receptor kinase requires coordinate interaction with $\mathrm{G}$ beta gamma subunits and lipid. J Biol Chem 270:11707-11710.

Premont RT, Koch WJ, Inglese J, and Lefkowitz RJ (1994) Identification, purification, and characterization of GRK5, a member of the family of G protein-coupled receptor kinases. J Biol Chem 269:6832-41.

Prossnitz ER, Kim CM, Benovic JL, and Ye RD (1995) Phosphorylation of the $\mathrm{N}$-formyl peptide receptor carboxyl terminus by the $\mathrm{G}$ protein-coupled receptor kinase, GRK2. J Biol Chem 270:1130-1137.

Ray K, Kunsch C, Bonner LM, and Robishaw JD (1995) Isolation of cDNA clones encoding eight different human $\mathrm{G}$ protein gamma subunits, including three novel forms designated the gamma 4 , gamma 10 , and gamma 11 subunits. J Biol Chem 270:21765-21771.

Sawutz D, Kalinyak K, Whitsett J, and Johnson C (1984) Histamine $\mathrm{H}_{2}$ receptor desensitization in HL-60 human promyelocytic leukemia cells. $J$ Pharmacol Exp Ther 231:1-6.

Shayo C, Davio C, Brodsky A, Mladovan A, Lemos Legnazzi B, Rivera E, and Baldi A (1997) Histamine modulates the expression of c-fos through cyclic AMP production via the $\mathrm{H}_{2}$ receptor in the human promonocytic cell line U-937. Mol Pharmacol 51:983-990.

Shetzline MA, Premont RT, Walker JKL, Vigna SR, and Caron MG (1998) A role for receptor kinases in the regulation of class II G protein-coupled receptors. J Biol Chem 273:6756-6762.

Smit M, Leurs R, Shukrula S, Bast A, and Timmerman H (1994) Rapid desensitization of the histamine $\mathrm{H}_{2}$ receptor on the human monocytic cell line U937. Eur $J$ Pharmacol 288:17-25.

Stoffel RH, Randall RR, Premont RT, Lefkowitz RJ, and Inglese J (1994) Palmitoylation of $\mathrm{G}$ protein-coupled receptor kinase, GRK6. Lipid modification diversity in the GRK family. J Biol Chem 269:27791-27794.

Teramoto H, Crespo P, Coso OA, Igishi T, Xu N, and Gutkind JS (1996) The small GTP-binding protein rho activates c-Jun N-terminal kinases/stress-activated protein kinases in human kidney $293 \mathrm{~T}$ cells. Evidence for a Pak-independent signaling pathway. J Biol Chem 271:25731-25734

Watson AJ, Aragay AM, Slepak VZ, and Simon MI (1996) A novel form of the G protein beta subunit Gbeta5 is specifically expressed in the vertebrate retina. J Biol Chem 271:28154-28160.

Address correspondence to: Carina Shayo, Ph.D., Institute of Biology and Experimental Medicine, Obligado 2490 (1428) Buenos Aires, Argentina. Email: cshayo@dna.uba.ar 